\title{
Effects of sodium nitrite treatment on the fermentation quality of red clover-grass silage harvested at two dry matter concentrations and inoculated with clostridia
}

\author{
Walter König, Emilia König, Kari Elo, Aila Vanhatalo and Seija Jaakkola \\ Department of Agricultural Sciences, P.O. Box 28, Fl-00014 University of Helsinki, Finland \\ e-mail: walter.konig@helsinki.fi
}

\begin{abstract}
Legumes are particularly susceptible to clostridial fermentation when ensiled because of their high buffering capacity and water-soluble carbohydrate contents. The aim of the study was to investigate if a sodium nitrite treatment (900 $\mathrm{g} \mathrm{t}^{-1}$ herbage in fresh matter [FM]) impairs butyric acid fermentation of red clover-timothy-meadow fescue silage compared with formic acid-treated $\left(4 \mathrm{I} \mathrm{t}^{-1} \mathrm{FM}\right)$ and untreated silage. The sward was harvested after wilting at low dry matter (DM) (LDM, $\left.194 \mathrm{~g} \mathrm{~kg}^{-1}\right)$ and high DM (HDM, $\left.314 \mathrm{~g} \mathrm{~kg}^{-1}\right)$ concentrations and half of the herbage batches were inoculated with Clostridium tyrobutyricum spores before additive treatments. No butyric acid fermentation was observed in HDM silages probably because of the relatively high DM and nitrate contents of the herbage mixture. In LDM silage butyric acid was detected only in formic acid-treated silage, and the number of clostridia copies was higher in formic acid-treated than in sodium nitrite treated silage. Sodium nitrite treatment was superior to FA treatment in suppressing clostridial fermentation in the LDM silages.
\end{abstract}

Key words: clostridia, formic acid, nitrite, silage additive, legumes

\section{Introduction}

Clostridia can be found in silage primarily because of soil and slurry contamination during harvesting. They can be either saccharolytic or proteolytic, and some consume lactic acid, which causes an undesirable rise in silage $\mathrm{pH}$ (Muck 2010). Clostridial growth in silage is favoured by high ambient temperature $\left(>25-30{ }^{\circ} \mathrm{C}\right)$, high buffering capacity (BC), and low dry matter (DM) and water-soluble carbohydrate (WSC) contents of forage (Pahlow et al. 2003). Clostridia form spores that can survive harsh conditions like low pH values. At the vegetative stage they in many ways reduce silage nutritive value and cause health problems for animals (Queiroz et al. 2018) and problems for semi-hard and hard cheese production (Driehuis 2013).

Weissbach et al. (1974) discovered that increasing herbage DM content and fermentability coefficient (FC) higher than 45 predicts butyric acid-free silages. The FC combines herbage DM and the quotient of WSC/BC by the formula: $\mathrm{FC}=\mathrm{DM}\left(\mathrm{g} \mathrm{kg}^{-1}\right) / 10+8 \times \mathrm{WSC}\left(\mathrm{g} \mathrm{kg}^{-1} \mathrm{DM}\right) / \mathrm{BC}\left(\mathrm{g} \mathrm{kg}^{-1} \mathrm{DM}\right)(\mathrm{Schmidt}$ et al. 1971) provided that herbage nitrate content is $\geq 4.4 \mathrm{~g} \mathrm{~kg}^{-1} \mathrm{DM}$ (Kaiser and Weiss 1997). Nevertheless, Driehuis and van Wikselaar (2000) found butyric acid amounts up to $18.7 \mathrm{~g}^{-1} \mathrm{~kg}$ DM in silages with a DM content ranging from 368 to $674 \mathrm{~g} \mathrm{~g}^{-1} \mathrm{~kg}^{\mathrm{DM}}$. The explanation could be related to herbage and silage osmolality (Hoedtke 2007). Osmolality is defined as the number of solute particles in one kg of solvent (Koeppen and Stanton 2012). According to Xiao et al. (2017) increasing external osmolality restricts bacterial cell growth. Since lactic acid bacteria have a better osmotolerance than clostridia, higher external osmolality has a positive effect on improving silage quality (Hoedtke 2007). The pH value which impairs clostridia growth decreases with decreasing DM content of the ensiled forage. In addition, the inhibitive effect of $\mathrm{pH}$ depends on the clostridia species, type of acid, and particularly on the concentration of undissociated acid molecules as reviewed by McDonald et al. (1991). Formic acid (pKa 3.77) has a stronger acidity than, e.g. acetic acid ( $\mathrm{pKa}=4.8$ ), but the concentration of the undissociated molecules is lower compared to other aliphatic carboxylic acids at same pH levels (Lück and Jager 1995). This may explain at least partly the differences in the effects of formic acid in inhibiting clostridia and butyric acid fermentation.

The antimicrobial effect of sodium nitrite is based on the released nitrous acid and the disproportionation reaction of nitrous acid into nitrate and nitric oxide (Quastel and Woolridge 1927). Nitric oxide and nitrite bind to the amino groups of the dehydrogenase system of the microbe cell (e.g. pyruvate dehydrogenase complex) which impairs cell growth (Woods et al. 1981, Woods and Wood 1982). Lactic acid bacteria do not possess a pyruvate dehydrogenase system. They are utilizing a lactate dehydrogenase instead of forming lactate from pyruvate (Garvie 1980). The pyruvate dehydrogenase is more receptive to nitric oxide than lactate dehydrogenase, and therefore, lactic acid bacteria are more resistant to nitrite than clostridia. 
Silage quality along with aerobic stability has increased when a mixture of sodium nitrite (SN) and hexamethylene tetraamine (HMTA) and SN together with sodium benzoate (SB) and sodium propionate (SP) have been used as silage additive (Hellberg 1967, Lingvall and Lättemäe 1999, Knicky and Spörndly 2009). Hexamethylene tetraamine releases formaldehyde which can react in diverse ways with amino acids, proteins and enzymes. However, according to Knicky and Spörndly (2009) and König et al. (2019), the addition of HMTA to SN-mixtures did not improve silage quality.

The preservation of legumes is challenging because of low DM content, high buffering capacity, relatively low WSC content and low nitrate content (König et al. 2017). Therefore, butyric acid fermentation in legume silages is common (Driehuis 2013). König et al. (2017) found that an additive based on a mixture of hexamethylene tetraamine (HMTA) and sodium nitrite (SN) impaired clostridia populations in white lupin-wheat silages more effectively than formic acid. The effect was not depending on the DM of the herbage. Red clover is the most commonly used forage legume for silage production in Finland. However, little information is available on how sodium nitrate as a sole additive inhibits clostridial fermentation in red clover-based silage harvested at different DM concentrations.

The main target of this study was to investigate if a sodium nitrite solution improves red clover-grass silage quality and impairs butyric acid fermentation compared with formic acid-treated and untreated silage. Two experiments were conducted to study the effect of additive treatments on the quality of wilted low dry matter (LDM, targeting at $200 \mathrm{~g} \mathrm{~kg}^{-1}$ ) and wilted high dry matter (HDM, targeting at $300 \mathrm{~g} \mathrm{~kg}^{-1}$ ) silage without and with inoculation of clostridia spores. We hypothesized that irrespective of the DM content of ensiled herbage (200 or $\left.300 \mathrm{~g} \mathrm{~kg}^{-1}\right) 1$ ) both sodium nitrite and formic acid reduce butyric acid fermentation products and clostridia spores compared to the untreated control silage and 2) sodium nitrite treatment is superior to formic acid treatment for its effect on butyric acid amount and clostridia spore counts in silage.

\section{Material and methods}

\section{Treatments and silage preparation}

The study comprised two ensiling experiments. The field area used for the experiments was a second-year legume-grass mixture of red clover (Trifolium pratense), timothy (Phleum pratense) and meadow fescue (Festuca pratensis) at the Viikki Research Farm of the University of Helsinki, Finland $\left(60^{\circ} \mathrm{N}, 25^{\circ} \mathrm{E}\right)$. The field was not fertilized in spring. The grass was cut on $9^{\text {th }}$ of August 2016 as a second cut of the summer using a disc mower (Krone EasyCut 3210 CV, Maschinenfabrik Bernard Krone GmbH, Spelle, Germany). Representative samples were collected from the experimental field area for botanical analyses before harvesting. The samples were taken from six randomly chosen areas of $0.25 \mathrm{~m}^{2}$ of size.

After cutting the herbage was wilted on the field in experiment 1 (Exp. 1) for 21 hours to get a low DM (LDM) silage and in experiment 2 (Exp. 2) for $45 \mathrm{~h}$ to get a high DM (HDM) silage. During wilting, the weather was partly cloudy with some light rain showers and average temperature was $18^{\circ} \mathrm{C}$. After wilting, a batch of the herbage was gathered from the field and chopped using a laboratory chopper (Winter climbers ${ }^{\circledR}$, Ried Im Innkreis, Austria) to give a chop-length of 1-4 cm. After that, the herbage was thoroughly mixed, and a batch of herbage for each silo was randomly collected, weighed and filled into a 1.5 I glass silo (Weck ${ }^{\circledR}$, Wher-Oflingen, Germany). Four replicate silos were made per treatment. The fermentation gases were allowed to leak through the rubber seal between glass silo and lid. The amount of herbage filled into a silo was $900 \mathrm{~g}$ (LDM) and $750 \mathrm{~g}$ (HDM). The density of the LDM and HDM compacted herbage was $119 \mathrm{~kg} \mathrm{DM} \mathrm{m}^{-3}$ and $157 \mathrm{~kg} \mathrm{DM} \mathrm{m}^{-3}$, respectively.

Clostridium tyrobutyricum spores were produced (Bionautit, Helsinki, Finland) and used to inoculate the herbages before ensiling to increase the challenge for silage additives. C. tyrobutyricum strain DSM 2637 was obtained from the Leibniz Institute DSMZ-German Collection of Microorganisms and Cell Cultures GmbH. Strain DSM 2637 was transferred into $5 \mathrm{ml}$ of RCM broth (Reinforced Clostridium Medium, LAB M) and grown for two days at $30^{\circ} \mathrm{C}$ under anaerobic conditions in an anaerobic chamber. $C$. tyrobutyricum spores were produced according to Klijn et al. (1995) with some modifications. Spores were produced by growing $100 \mathrm{ml}$ cultures in RCM broth for 8 days at $30{ }^{\circ} \mathrm{C}$ in an anaerobic chamber. In total, $300 \mathrm{ml}$ of C. butyricum cultures were centrifuged (15 min, $3000 \mathrm{~g}$ ), and pellet containing spores were suspended in $30 \mathrm{ml}$ of skimmed milk (LAB M) and stored in small portions at $-20^{\circ} \mathrm{C}$ ("suspension II"). After 8 days of storage at $-20^{\circ} \mathrm{C}$, the number of spores were estimated as colony forming units (CFU) by plate counts on RCM agar. Plates were incubated for six days at $30^{\circ} \mathrm{C}$ in an anaerobic chamber. 
Half of the silos were filled with herbage batch inoculated with C. tyrobutyricum at the rate of $1 * 10^{5}$ colony forming units (cfu) $\mathrm{g}^{-1}$ fresh weight (FW). The inoculation solution was spread with a pipette while herbage was simultaneously thoroughly mixed. Immediately thereafter the herbage was treated in the same way with 4 I t ${ }^{-1} \mathrm{FM}$ formic acid (FA; Sigma Aldrich, St. Louis, USA; $950 \mathrm{~g} \mathrm{~kg}^{-1}$ ) or with $900 \mathrm{~g} \mathrm{t}^{-1} \mathrm{FM}$ sodium nitrite (SN; aqueous solution, Sigma Aldrich, St. Louis, USA) (Table 1). The additives were applied as a water solution with a volume of $10 \mathrm{ml} \mathrm{kg}^{-1}$ $\mathrm{FM}$, including additive and water. For the control (CON) silages, the herbage was treated with $10 \mathrm{ml} \mathrm{kg}^{-1} \mathrm{FM}$ tap water. Silos were stored at ambient room temperature $\left(20-22^{\circ} \mathrm{C}\right)$ and opened 106 days after ensiling.

Table 1. Additive treatments and clostridial spore inoculation of red clover-based silages

\begin{tabular}{lcc}
\hline Additive/inoculation treatment & Additive/inoculation & Application rate of effective substance \\
\hline Control (CON) & No additive & - \\
Formic acid (FA) & $\mathrm{CH}_{2} \mathrm{O}_{2}\left(950 \mathrm{~g} \mathrm{~kg}^{-1}\right)$ & Formic acid $4 \mathrm{I} \mathrm{t}^{-1} \mathrm{FM}$ \\
Sodium nitrite (SN) & $\mathrm{NaNO}_{2}$ & Na-nitrite $900 \mathrm{~g} \mathrm{t}^{-1} \mathrm{FM}$ \\
CON + clostridia & Clostridium tyrobutyricum & $1 \times 10^{5} \mathrm{cfu} \mathrm{g}^{-1} \mathrm{FM}$ \\
FA + clostridia & Clostridium tyrobutyricum & $1 \times 10^{5} \mathrm{cfu} \mathrm{g}^{-1} \mathrm{FM}$ \\
SN + clostridia & Clostridium tyrobutyricum & $1 \times 10^{5} \mathrm{cfu} \mathrm{g}^{-1} \mathrm{FM}$ \\
\hline
\end{tabular}

$\mathrm{cfu}=$ colony forming unit; $\mathrm{FM}=$ fresh matter

\section{Chemical analysis and aerobic stability}

A pre-ensiling sample of the herbage was taken from the chopped herbage for immediate DM determination and for later analyses. Dry matter content was determined by drying the samples at $105^{\circ} \mathrm{C}$ for $24 \mathrm{~h}$ in an oven (Memmert, Memmert $\mathrm{GmbH}$, Schwabach, Germany). Fresh samples were frozen $\left(-20^{\circ} \mathrm{C}\right)$ for analyses of buffering capacity (BC), total and soluble nitrogen, water-soluble carbohydrates (WSC), nitrate and clostridia. For analyses of ash, neutral detergent fibre (NDF) and in vitro digestibility samples were dried at $50{ }^{\circ} \mathrm{C}$ for 48 hours in a ventilated drying chamber (Memmert, Memmert Gmbh, Schwabach, Germany). After that, the samples were ground through a 1-mm sieve using a laboratory mill (KT-3100, Koneteollisuus Oy, Helsinki, Finland). Ash was determined by keeping the samples at $550^{\circ} \mathrm{C}$ for $16-17$ hours in an oven (Nabertherm B150, Nabertherm GmbH, Bremen, Germany). All other chemical methods and calculation of digestible organic matter in DM (DOMD) were reported in detail by König et al. (2017).

After opening the silos, every silage was mixed, and samples were taken for immediate DM, pH (SevenCompactTM S220, Mettler-Toledo Ltd, Leicester, Great Britain) and aerobic stability analyses. Samples for fermentation quality and clostridia were stored at $-20^{\circ} \mathrm{C}$ for later analyses. The DM content of silages was determined similar to herbage samples and corrected for the loss of volatile compounds (lactic acid, VFA (volatile fatty acids), $\mathrm{NH}_{3}-\mathrm{N}$ and ethanol) according to Huida et al. (1986). The volatile compound concentrations were analysed as reported by Puhakka et al. (2016). Silage WSC content was investigated with the same method as herbage samples.

Aerobic stability was measured over a period of 12 days and expressed as time elapsed until the temperature rose $2{ }^{\circ} \mathrm{C}$ over the mean ambient temperature $\left(22^{\circ} \mathrm{C}\right)$. A more detailed description of the method is given by König et al. (2017).

\section{Clostridium analyses using qPCR}

For each DNA extraction, 30 grams of pre-ensiling herbage or silage were weighed, and samples were homogenized in $200 \mathrm{ml}$ of ultrapure water. Homogenates were divided into three $50 \mathrm{ml}$ tubes and centrifuged using $10000 \mathrm{~g}$ for $15 \mathrm{~min} .200 \mathrm{mg}$ of pellet per sample was collected for DNA extraction. The DNA extraction was conducted using the Macherey-Nagel NucleoSpin ${ }^{\circledR}$ Soil kit (Macherey-Nagel GmbH and Co. Kg, Düren, Germany) by using SL1 lysis buffer without SX enhancer as described by the manufacturer. 
The DNA sequences of PCR primers for Clostridium butyricum, C. tyrobutyricum, $C$. sporogenes and $C$. perfringens were as in our previous study (König et al. 2017). The qPCR reactions were performed in a Lightcycler 480 optical 384-well plate (Roche Diagnostics, Mannheim, Germany) with a total volume of $10 \mu \mathrm{l}$. Using EpMotion 5075 pipetting system (Eppendorf, Hamburg, Germany), $2.5 \mu \mathrm{l}$ of diluted DNA and $7.5 \mu \mathrm{l}$ of the master mixture was added. The master mixture was composed of $5 \mu \mathrm{l} 2$ X SYBR Green master mix (Roche Diagnostics), $0.5 \mu \mathrm{l}\left(5 \mathrm{pmol}^{-1} \mathrm{l}^{-1}\right)$ each of forward and reverse primers, and $1.5 \mu \mathrm{l}$ DNase/RNase-free water.

Lightcycler 480 instrument (Roche Diagnostics) was used for qPCR. Each DNA sample was run in quadruplicate. The temperature profile of the qPCR was as follows: initial denaturation step for 5 min at $95{ }^{\circ} \mathrm{C}$, followed by 45 amplification cycles for $10 \mathrm{~s}$ at $95{ }^{\circ} \mathrm{C}, 20 \mathrm{~s}$ at $55^{\circ} \mathrm{C}$, and $30 \mathrm{~s}$ at $72{ }^{\circ} \mathrm{C}$. A melting curve analysis was run at the end of the PCR program.

The standard curves were generated using DNA extracted from the following reference strains: $C$. perfringens DSM strain 756, C. sporogenes DSM strain 795, C. butyricum DSM 10702 and C. tyrobutyricum DSM 2637 (Leibniz-Institute DSMZ German Collection of Microorganisms and Cell Cultures GmbH, Germany). Six standard dilutions (from 0.004 to $12.5 \mathrm{ng} \mathrm{\mu l}^{-1}$ ) were always amplified on the same plate and using the same primers and reaction conditions as samples. Each standard dilution was run in triplicate in the qPCR. The raw data from Lightcycler 480 was analyzed with LinRegPCR (Ruijter et al. 2009). Average numbers of Clostridium gene copies were calculated per gram of silage.

\section{Calculations and statistical analysis}

The fermentation coefficient for pre-ensiling herbages was calculated as FC= DM $\left(\mathrm{g} \mathrm{kg}^{-1}\right) / 10+8 \times \mathrm{WSC}\left(\mathrm{g} \mathrm{kg}^{-1} \mathrm{DM}\right) /$ $\mathrm{BC}\left(\mathrm{g} \mathrm{kg}^{-1} \mathrm{DM}\right)$ (Schmidt et al. 1971). The minimum DM content of ensiled herbage $\left(\mathrm{DM}_{\min }\right)$ needed to ensure high fermentation quality of silage was calculated using the equation $\mathrm{DM}_{\min }\left(\mathrm{g} \mathrm{kg}^{-1}\right)=450-80 \times \mathrm{WSC}\left(\mathrm{g} \mathrm{kg}^{-1} \mathrm{DM}\right) / \mathrm{BC}^{-}$ (g kg-1 DM) (Weissbach 1999). A corrected $\mathrm{N}$ content was calculated by deducting all added SN nitrogen from the analyzed amount of total nitrogen and ammonia nitrogen.

The results for fermentation quality parameters and clostridial copy numbers were statistically analyzed separately for the two trials. Before analyses logarithmic transformations were done for clostridial copy numbers. Normally distributed variables were analyzed by ANOVA using the Mixed procedure of SAS (SAS 9.3, Institute Inc., Cary, NC) with a model yij $=\mu+\alpha i+\varepsilon i j$, where yij is the overall mean observation, $\alpha$ i the effect of treatment and हij the error term.

The effects of additives and clostridia addition (no clostridia inoculation vs clostridia inoculation) and their interaction were first tested using orthogonal contrasts. The inoculation with clostridia had only minor numerical and statistical effects on silage quality, obviously due to the very high epiphytic clostridial contamination of herbage. Therefore, the data were pooled over inoculation treatments and only the differences between the additive treatment means were tested using Tukey's test.

Non-normal distributed data were tested with the Kruskal-Wallis non-parametric test (SPSS, version 21, IBM, Armonk, USA) and when significant, the differences between the treatment means were analyzed by pairwise testing (Dunn-Bonferroni). Statistically significant differences $(p<0.05)$ between the treatments are expressed using different letters $(a, b)$.

\section{Results}

\section{Herbage characteristics prior to ensiling}

The ensiled herbage was composed mainly of red clover (Table 2). The DM content was $199 \mathrm{~g} \mathrm{~kg}^{-1}$ and $314 \mathrm{~g} \mathrm{~kg}^{-1}$ for the LDM and HDM herbage, respectively. Since also the WSC content was slightly higher and BC lower in HDM than LDM herbage the calculated FC was higher for HDM (42) than LDM (28) herbage. However, on FM basis the WSC content was almost twice as high in HDM as in LDM herbage. The LDM herbage contained 13.3 log copies $\mathrm{g}^{-1}$ FM and the HDM herbage contained 9.9 log copies $\mathrm{g}^{-1} \mathrm{FM}$ of clostridia ssp. The nitrate content was the same for both LDM and HDM herbage (4 $\left.\mathrm{g} \mathrm{kg}^{-1} \mathrm{DM}\right)$. 
Table 2. Botanical and chemical composition and ensilability characteristics of low dry matter (LDM) and high dry matter (HDM) red clover-grass herbage ( $\mathrm{g} \mathrm{kg}^{-1}$ dry matter, unless otherwise stated)

\begin{tabular}{|c|c|c|}
\hline & LDM & HDM \\
\hline \multicolumn{3}{|l|}{ Botanical analysis, $\mathrm{g} \mathrm{kg}^{-1}$ fresh matter } \\
\hline Trifolium pratense & & 659 \\
\hline Phleum pratense / Festuca pratensis & & 311 \\
\hline Weeds & & 30 \\
\hline \multicolumn{3}{|l|}{ Chemical composition } \\
\hline Dry matter (DM), $\mathrm{g} \mathrm{kg}^{-1}$ & 199 & 314 \\
\hline Calculated $\mathrm{DM}_{\min ^{\prime}} \mathrm{g} \mathrm{kg}^{-1} 1$ ) & 366 & 345 \\
\hline Ash & 88.3 & 83.3 \\
\hline Crude protein & 188 & 177 \\
\hline Soluble $\mathrm{N}, \mathrm{g} \mathrm{kg}^{-1} \mathrm{~N}$ & 367 & 318 \\
\hline Neutral detergent fibre & 460 & 467 \\
\hline Water soluble carbohydrates (WSC) & 82.6 & 95.7 \\
\hline WSC, $\mathrm{g} \mathrm{kg}^{-1}$ fresh matter & 16.4 & 30.1 \\
\hline Nitrates & 4.0 & 4.0 \\
\hline In vitro digestible organic matter & 679 & 673 \\
\hline Buffering capacity (BC) as lactic acid $\mathrm{g} \mathrm{kg}^{-1} \mathrm{DM}$ & 78.6 & 72.6 \\
\hline $\mathrm{BC}$ as $\mathrm{mEq} \mathrm{kg}{ }^{-1} \mathrm{DM}$ & 872 & 805 \\
\hline Fermentation coefficient ${ }^{21}$ & 28.3 & 42.0 \\
\hline Clostridia, log copies $\mathrm{g}^{-1}$ fresh matter & 13.3 & 9.9 \\
\hline
\end{tabular}

\section{Silage aerobic stability and fermentation quality}

The additive treatments are compared within experiments, not between LDM and HDM silages in experiments 1 and 2, respectively. All the 48 investigated silages were aerobically stable for 12 days, and therefore no results are presented.

The effects of additives on fermentation quality of silages are presented in Tables 3 and 4. In Exp. 1, no differences were observed between additive treatments in silage $\mathrm{pH}$ while in Exp. 2 the $\mathrm{pH}$ of FA silage was higher compared with other silages. In both experiments, FA decreased ammonia-N proportion compared to CON and SN silages. After correcting ammonia-N for added nitrogen, the proportion in both FA and SN silage was lower when compared with CON silage. In HDM silages less ammonia-N was observed in SN than in CON silage and less corrected ammonia- $\mathrm{N}$ in SN than in FA treated silage.

The use of FA resulted both in LDM and HDM silages in lower concentrations of lactic and acetic acids and higher amounts of WSC compared with the untreated control and SN treated silages. In Exp. 2, acetic acid content was lower in SN than CON silage.

In both experiments, SN silage ethanol concentration was lower than that of FA silage, and in Exp. 2 also lower than in CON silage. In contrast to the other treatments, FA did not prevent butyric acid fermentation in Exp. 1. No butyric acid was detected in Exp. 2. The sum of clostridia copy numbers in Exp. 1 was higher in FA silage than in SN silage and in Exp. 2 higher than in CON silage. In both experiments, the copy number of $C$. tyrobutyricum was higher in FA than CON silages. 
Table 3. The effect of additive treatment on wilted red clover-based silage fermentation quality $\left(\mathrm{g} \mathrm{kg}^{-1} \mathrm{dry}_{\text {matter, if not }}\right.$ otherwise stated) and number of clostridia as log copies $\mathrm{g}^{-1}$ fresh matter $(n=4)$ (experiment 1 )

\begin{tabular}{|c|c|c|c|c|}
\hline & \multicolumn{3}{|c|}{ Additive treatments } & \multirow[t]{2}{*}{ SEM } \\
\hline & Control & Formic acid & Na-nitrite & \\
\hline Dry matter, $\mathrm{g} \mathrm{kg}^{-1}$ & $213^{b}$ & $204^{\mathrm{a}}$ & $212^{\mathrm{b}}$ & 1.5 \\
\hline $\mathrm{pH}^{11}$ & 4.08 & 4.08 & 4.05 & 0.023 \\
\hline Ammonia- $\mathrm{N}^{11}, \mathrm{~g} \mathrm{~kg}^{-1} \mathrm{~N}$ & $81.0^{\mathrm{b}}$ & $46.0^{\mathrm{a}}$ & $74.5^{b}$ & 2.43 \\
\hline Cor Ammonia- $\mathrm{N}^{11}, \mathrm{~g} \mathrm{~kg}^{-1} \mathrm{~N}$ & $81.0^{\mathrm{b}}$ & $46.0^{\mathrm{a}}$ & $44.9^{\mathrm{a}}$ & 2.41 \\
\hline Water soluble carbohydrates ${ }^{1)}$ & $4.3^{\mathrm{a}}$ & $90.2^{\mathrm{b}}$ & $4.3^{\mathrm{a}}$ & 2.18 \\
\hline Lactic acid ${ }^{1)}$ & $133^{b}$ & $23^{\mathrm{a}}$ & $136^{b}$ & 1.9 \\
\hline Acetic acid & $36.1^{\mathrm{b}}$ & $9.0^{\mathrm{a}}$ & $36.4^{b}$ & 0.70 \\
\hline Butyric acid ${ }^{1)}$ & $0.00^{\mathrm{a}}$ & $2.68^{b}$ & $0.00^{\mathrm{a}}$ & 1.229 \\
\hline Ethanol $^{11}$ & $3.25^{\mathrm{ab}}$ & $5.42^{\mathrm{b}}$ & $1.38^{\mathrm{a}}$ & 0.360 \\
\hline Clostridia, sum ${ }^{11}$ & $10.4^{\mathrm{ab}}$ & $11.0^{\mathrm{b}}$ & $10.3^{\mathrm{a}}$ & 0.20 \\
\hline C. butyricum ${ }^{1)}$ & 10.0 & 10.4 & 9.9 & 0.26 \\
\hline C. tyrobutyricum ${ }^{1)}$ & $8.77^{\mathrm{a}}$ & $10.18^{b}$ & $8.95^{\mathrm{ab}}$ & 0.560 \\
\hline C. perfringens ${ }^{1)}$ & 8.12 & 7.56 & 7.56 & 0.226 \\
\hline C. sporogenes ${ }^{1)}$ & 6.19 & 6.77 & 6.13 & 0.262 \\
\hline
\end{tabular}

1) Kruskal-Wallis non-parametric test followed by Dunn-Bonferroni pairwise test, otherwise Tukey's test; Means followed by different superscript letters in rows are statistically different at $p<0.05 ; \mathrm{SEM}=$ Standard error of the means; Cor Ammonia-N = ammonia-N proportion is corrected by deducting all nitrogen applied through $\mathrm{Na}$-nitrite additive

Table 4. The effect of additive treatment on wilted red clover-based silage fermentation quality $\left(\mathrm{g} \mathrm{kg}^{-1} \mathrm{dry}\right.$ matter, if not otherwise stated) and number of clostridia as log copies $\mathrm{g}^{-1}$ fresh matter $(n=4)$ (experiment 2)

\begin{tabular}{|c|c|c|c|c|}
\hline & \multicolumn{3}{|c|}{ Additive treatments } & \multirow[t]{2}{*}{ SEM } \\
\hline & Control & Formic acid & Na-nitrite & \\
\hline Dry matter, $\mathrm{g} \mathrm{kg}^{-1}$ & 322 & 322 & 325 & 4.1 \\
\hline $\mathrm{pH}$ & $4.12^{\mathrm{a}}$ & $4.19^{b}$ & $4.10^{\mathrm{a}}$ & 0.008 \\
\hline Ammonia- $\mathrm{N}, \mathrm{g} \mathrm{kg}^{-1} \mathrm{~N}$ & $71.7^{c}$ & $49.0^{\mathrm{a}}$ & $65.7^{\mathrm{b}}$ & 0.90 \\
\hline Cor Ammonia-N, $\mathrm{g} \mathrm{kg}^{-1} \mathrm{~N}$ & $71.7^{c}$ & $49.0^{\mathrm{b}}$ & $46.0^{\mathrm{a}}$ & 0.74 \\
\hline Water soluble carbohydrates ${ }^{11}$ & $14.1^{\mathrm{a}}$ & $79.3^{b}$ & $18.7^{\mathrm{a}}$ & 1.85 \\
\hline Lactic acid ${ }^{11}$ & $118^{\mathrm{a}}$ & $37^{\mathrm{b}}$ & $110^{\mathrm{a}}$ & 1.9 \\
\hline Acetic acid & $26.5^{c}$ & $9.0^{\mathrm{a}}$ & $24.1^{\mathrm{b}}$ & 0.53 \\
\hline Butyric acid & 0.00 & 0.00 & 0.00 & 0.000 \\
\hline Ethanol & $3.67^{b}$ & $3.46^{\mathrm{b}}$ & $1.00^{\mathrm{a}}$ & 0.202 \\
\hline Clostridia, sum ${ }^{1)}$ & $10.4^{\mathrm{a}}$ & $11.3^{\mathrm{b}}$ & $11.2^{\mathrm{ab}}$ & 0.56 \\
\hline C. butyricum & 9.86 & 9.87 & 9.82 & 0.040 \\
\hline C. tyrobutyricum ${ }^{1)}$ & $10.2^{\mathrm{a}}$ & $10.6^{\mathrm{b}}$ & $10.3^{\mathrm{ab}}$ & 0.08 \\
\hline C. perfringens & 6.98 & 7.17 & 7.24 & 0.148 \\
\hline C. sporogenes ${ }^{1)}$ & 6.06 & 7.79 & 7.09 & 1.110 \\
\hline
\end{tabular}

1) Kruskal-Wallis non-parametric test followed by Dunn-Bonferroni pairwise test, otherwise Tukey's test; Means followed by different superscript letters in rows are statistically different at $p<0.05$; SEM $=$ Standard error of the means; Cor Ammonia- $\mathrm{N}$ $=$ ammonia- $\mathrm{N}$ proportion is corrected by deducting all nitrogen applied through $\mathrm{Na}$-nitrite additive 


\section{Discussion \\ Herbage}

The sward used in this experiment comprised mostly red clover, which, through its ensilability characteristics affects silage fermentation quality as shown by Dewhurst et al. (2003). Both red clover-grass mixtures exposed relatively low WSC contents, high buffer capacities and fermentability coefficients (FC) below 45, which according to Weissbach (1968) predicts susceptibility for butyric acid fermentation.

The WSC concentration of the crop is considered a key factor when ensiling low DM herbage. The herbage should contain enough WSC to be fermented by the lactic acid bacteria to obtain a low pH and inhibitory concentrations of lactic acid and acetic acid. The fermentation coefficient $(F C=28.3)$ and the calculated minimum $D^{\prime}\left(D M_{\min }=\right.$ $366 \mathrm{~g} \mathrm{~kg}^{-1}$ DM) content, as well as the WSC content in LDM herbage, were below their limits according to Weissbach et al. (1974) and therefore, butyric acid fermentation was expected. The HDM herbage had an FC of 42 and $30 \mathrm{~g} \mathrm{~kg}^{-1}$ WSC in the fresh matter, which is regarded as moderately difficult to ensile (EFSA 2006). According to Weissbach et al. (1974), the quotient of WSC/BC should be more than 2.5 to obtain butyric acid-free silages. In our experiments, the WSC/BC ratio were 1.05 (LDM) and 1.32 (HDM).

Wilting improved the FC of the herbage in the present experiment from 28 (LDM) to 42 (HDM) and simultaneously butyric acid fermentation was inhibited in HDM silages. Wilting is directly linked to increasing osmolality of the herbage, which is the actual reason for the inhibition of clostridia. According to Hoedtke (2007), e.g. WSC, amino acids, alcohols and mineral ions are increasing the osmolality of the plants, whereas starch and other macromolecules decrease the osmolality due to their high mole masses. This induces that the plants osmolality varies during the growing process if WSC is used to build starch and amino acids for proteins. Hoedtke (2007) questioned the correlation between wilting and osmolality and introduced the term osmol kg ${ }^{-1} \mathrm{DM}$, which describes the different osmolality values between different plant groups with the same DM content. Plant osmolality has a direct impact on microbe osmotolerance and silage quality. Increased osmolality impairs microbial growth. Therefore, the DM content of herbage as a prediction tool for quality silage is less effective than the osmol $\mathrm{kg}^{-1} \mathrm{DM}$.

The additional inoculation with $C$. tyrobutyricum (log $5 \mathrm{cfu} \mathrm{g}^{-1}$ herbage) had no influence on the silage quality due to the highly contaminated herbage with clostridia copy numbers (log 13 DNA copies g-1 herbage). Hence, we combined the inoculated results with the uninoculated generating eight replicates per treatment. The reason for the herbage contamination with clostridia might be the problems with huge flocks of Canada geese (Branta canadensis) spoiling the research area with their droppings. Typical populations of clostridia on plants before ensiling are 1001000 endospores per g crop (Pahlow et al. 2003). According to König et al. (2017), the number of gene copies per bacterial genome may vary from 1 to 15, which equals approximately 200 bacteria cells and/or endospores per gram fresh weight. The high numbers of clostridia DNA copies in the herbage had little effect on butyric acid fermentation in both silages. Since our qPCR test did not separate the living spores and bacteria from the dead ones, we could assume that most of clostridia spores were inactive or damaged.

\section{Silages}

The fermentation quality of the FA treated silage compared with untreated silage was in both experiments as described in various publications earlier (Muck et al. 2017). Formic acid reduced protein degradation and fermentation as evidenced by low ammonia- $\mathrm{N}$ values and low lactic acid and acetic acid contents. The high residual WSC value was also characteristic to formic acid treatments. However, in LDM formic acid treatment did not prevent butyric acid formation compared with the control and the SN treatment. In HDM silage, formic acid treatment exposed higher $\mathrm{pH}$ values compared with control and $\mathrm{SN}$, which might be related to the application level. The applied amount of FA per $\mathrm{D}$ DM in HDM herbage was 12.7 I, which was 7.1 I less than in the LDM herbage. Despite of that, all HDM silages were free of butyric acid.

The reasons why FA treatment did not improve silage quality in LDM might be found in the buffering capacity, low DM content and low WSC content of the herbage. The immediate $\mathrm{pH}$-decrease of the herbage while applying FA, might have impaired enterobacteria to reduce nitrate to nitrite and clostridia by utilizing nitrate as an electron sink. As a consequence, the butyric acid fermentation pathway was employed. When nitrate is used as an electron acceptor, clostridia produces acetic acid instead of butyric acid (Spoelstra 1985). 
Control and FA silages had the same pH values, but their osmo-activity might be different. This could be one explanation for the susceptibility of LDM FA silage to butyric acid fermentation. Formic acid treated silage has less osmo-active substances because FA restricts typically the fermentation. The microbes in control and SN silages fermented the WSC to lactic acid, which converted 1 mole glucose into 2 moles lactic acid in the homofermentative pathway. The heterofermentative pathway converts 1 mole glucose into 1 mole lactic acid and 1 mole acetic acid or 1 mole ethanol. The fermentation of glucose increases the amounts of osmo-active particles and thus osmolality. Using FA as silage additive, the fermentation of the herbage has a minor effect on osmolality.

The fermentation profile of SN silages was similar to the control silages with the exception that the addition of SN decreased proteolytic activity. According to Cornforth (1996), protein-bound nitrite is of antimicrobial significance. The binding of nitrite to sulfide in sulfide containing proteins and enzymes is the important reaction in weakly acidic conditions as described by Byler et al. (1983). The sulfide area of the enzyme is usually the active part of the enzyme due to the nucleophilicity of sulfide. The binding of nitrite to the sulfide group inactivates the enzyme function. Carpenter et al. (1987) investigated clostridial ferredoxin and pyruvate-ferredoxin oxidoreductase activity of $C$. pasteurianum. They found that the inhibition of ferredoxin increased with increasing levels of sodium nitrite and concluded that the inactivation of ferredoxin and pyruvate-ferredoxin oxidoreductase by nitrite is at least partly the reason for the anti-botulinal effect of nitrite.

The decision to correct the ammonia- $\mathrm{N}$ values of $\mathrm{SN}$ silages is based on the fact that sodium nitrite releases nitrous acid in weak acidic environments. Nitrous acid degrades further into nitric oxide and nitrogen dioxide (Spoelstra 1985). During fermentation of carbohydrates by bacteria, these nitrous gases serve as an electron acceptor, which has the consequence that the fermentation pathway changes, e.g. enterobacteria form acetic acid instead of ethanol (Spoelstra 1985). A small part of the nitrous gases escapes into the atmosphere (5-25\%), but the rest is reduced to ammonia, which results in silages with elevated ammonia- $\mathrm{N}$ values. Since the elevated ammonia- $\mathrm{N}$ values are not linked to protein degradation, but to SN addition, we decided to correct the ammonia- $\mathrm{N}$ values by subtraction of the completely applied nitrite-N.

\section{Conclusions}

In both experiments, no butyric acid formation was observed in the untreated control silage. The absence of butyric acid was probably related to the nitrate content of the herbage which allowed clostridia to use it as an electron acceptor and to avoid the lower energy gaining pathway of butyric acid fermentation.

Sodium nitrite treatment was superior to FA treatment concerning butyric acid contents and clostridial copy numbers in the LDM silages. The restrictive effect of formic acid on silage lactic acid fermentation and the resulting minor influence on osmolality might explain butyric acid fermentation in FA treated silages. Clostridial copy numbers were generally very high in all silages due to the high epiphytic contamination of herbage. This may explain why only minor differences were detected between additive treatments. In conclusion, the sole sodium nitrite treatment is a possible alternative to formic acid as silage additive when ensiling difficult to ensile legume bi-crops.

\section{References}

Byler, D.M., Gosser, D.K. \& Susi, H. 1983. Spectroscopic estimation of the extent of S-nitrosothiol formation by nitrite action on sulfhydryl groups. Journal of Agricultural and Food Chemistry 31: 523-527. https://doi.org/10.1021/jf00117a015

Carpenter, C.E., Reddy, D.S. \& Cornforth, D.P. 1987. Inactivation of clostridial ferredoxin and pyruvate-ferredoxin oxidoreductase by sodium nitrite. Applied and Environmental Microbiology 53: 549-52.

Cornforth, D.P. 1996. Role of nitric oxide in treatment of foods. In: Lancaster, J.R. (ed.). Nitric Oxide: Principles and Actions. Academic Press, San Diego. p. 259-287. https://doi.org/10.1016/B978-012435555-2/50009-7

Dewhurst, R.J., Fisher, W.J., Tweed, J.K.S. \& Wilkins, R.J. 2003. Comparision of grass and legume silages for milk production. 1. Production responses with different levels of concentrate. Journal of Dairy Science 86: 2598-2611. https://doi.org/10.3168/jds. S0022-0302(03)73855-7

Driehuis, F. 2013. Silage and the safety and quality of dairy foods: a review. Agricultural and Food Science 22: 16-34. https://doi. org/10.23986/afsci.6699

Driehuis, F. \& van Wikselaar, P.G. 2000. The occurence and prevention of ethanol fermentation in high dry matter grass silages. Journal of The Science of Food and Agriculture 80:711-718. https://doi.org/10.1002/(SICI)1097-0010(20000501)80:6<711::AIDJSFA593>3.0.CO;2-6 
W. König et al. (2019) 28: 155-164

EFSA 2006. Opinion of the Scientific Panel on Additives and Products or Substances used in Animal Feed for the establishment of guidelines on the assessment of safety and efficacy of silage additives, on a request from the Commission under Article 7(5) of Regulation (EC) No 1831/2003. The EFSA Journal 349: 1-10. https://doi.org/10.2903/j.efsa.2006.349

Garvie, E.I. 1980. Bacterial Lactate Dehydrogenases. Microbiological Reviews 44: 106-139

Hellberg, A. 1967. A combination of nitrite and hexamine as an additive in the ensiling of herbage. Journal of the British Grassland Society 22: 289-292. https://doi.org/10.1111/j.1365-2494.1967.tb00542.x

Hoedtke, S. 2007. Die Quantifizierung der Osmolalität in Futterpflanzen und ihre Veränderung in verschiedenen Stadien der Silierung. Dissertation. Institut für Nutztierwissenschaften und Technologie der Agrar- und Umweltwissenschaftlichen Fakultät der Universität Rostock. 161 p. (in German).

Huida, L., Väätäinen, H. \& Lampila, M. 1986. Comparision of dry matter content in grass silages as determined by oven drying and gas chromatographic water analysis. Annales Agriculturae Fennia 25: 215-230.

Kaiser, E. \& Weiss, K. 1997. Zum Gärungsverlauf bei der Silierung von nitratarmem Grünfutter 2. Mitteilung: Gärungsverlauf bei Zusatz von Nitrat, Nitrit, Milchsäurebakterien und Ameisensäure. [On the fermentation process during ensiling of green forage low in nitrate. 2. Fermentation course with the addition of nitrate, nitrite, lactic acid bacteria and formic acid]. Archiv für Tierenährung 50: 187-200. https://doi.org/10.1080/17450399709386130

Klijn, N., Nieuwenhof, F.F.J., Hoolwerf, J.D., van der Waals, C.D.B. \& Weerkamp, A.H. 1995. Identification of Clostridium tyrobutyricum as the causative agent of late blowing in cheese by species-specific PCR amplification. Applied and Environmental Microbiology 61: 2919-2924.

Knicky, M. \& Spörndly, R. 2009. Sodium benzoate, potassium sorbate and sodium nitrite as silage additives. Journal of the Science of Food and Agriculture 89: 2659-2667. https://doi.org/10.1002/jsfa.3771

Koeppen, B. \& Stanton, B. 2012. Renal Physiology. 5th Edition. Mosby Physiology Monograph Series 2012. 256 p.

König, W., König, E., Weiss, K., Tuomivirta, T.T., Fritze, H., Elo, K., Vanhatalo, A. \& Jaakkola, S. 2019. Impact of hexamine addition to a nitrite-based additive on fermentation quality, Clostridia and Saccharomyces cerevisiae in a white lupin-wheat silage. Journal of the Science of Food and Agriculture 99: 1492-1500. https://doi.org/10.1002/jsfa.9322

König, W., Lamminen, M., Weiss, K., Tuomivirta, T.T., Sanz Muñoz, S., Fritze, H., Elo, K., Puhakka, L., Vanhatalo, A. \& Jaakkola, S. 2017. The effect of additives on the quality of white lupin-wheat silages passed by fermentation pattern and qPCR quantification of clostridia. Grass and Forage Science 72: 757-77. https://doi.org/10.1111/gfs.12276

Lingvall, P. \& Lättemäe, P. 1999. Influence of hexamine and sodium nitrite in combination with sodium benzoate and sodium propionate of fermentation and hygienic quality of wilted and long cut grass silage. Journal of the Science of Food and Agriculture 79:257-264. https://doi.org/10.1002/(SICI)1097-0010(199902)79:2<257::AID-JSFA186>3.0.CO;2-J

Lück, E. \& Jager, M. 1995. Chemische Lebensmittelkonservierung (Chemical food preservation), 3rd edn. Springer-Verlag Berlin, Heidelberg, GmbH. 273 p. https://doi.org/10.1007/978-3-642-57868-7

McDonald, P., Henderson, A.R. \& Heron, S.J.E. 1991. The biochemistry of silage 2nd edition. Chalcombe Publications, Marlow, UK. 340 p.

Muck, R.E. 2010. Silage microbiology and its control through additives. Revista Brasileira de Zootecnia (supl. especial) 39: 183191. https://doi.org/10.1590/S1516-35982010001300021

Muck, R.E., Nadeau, E.M.G., McAllister, T.A., Contreras-Govea, F.E., Santos, M.C. \& Kung Jr., L. 2017. Silage review: Recent advances and future uses of silage additives. Journal of Dairy Science 101: 3980-4000. https://doi.org/10.3168/jds.2017-13839. https://doi.org/10.3168/jds.2017-13839

Pahlow, G., Muck, R., Driehus, F., Oude Elferink, S.J.W.H. \& Spoelstra, S.F. 2003. Microbiology of Ensiling. In: Buxton, D.R., Muck, R.E. \& Harrison, J.H. (eds.). Silage Science and Technology. American Society of Agronomy, Inc. p. 31-93.

Puhakka, L., Jaakkola, S., Simpura, I., Kokkonen, T. \& Vanhatalo, A. 2016. Effects of replacing rapeseed meal with fava bean at 2 concentrate crude protein levels on feed intake, nutrient digestion, and milk production in cows fed grass silage-based diets. Journal of Dairy Science 99: 7993-8006. https://doi.org/10.3168/jds.2016-10925. https://doi.org/10.3168/jds.2016-10925

Quastel, J.H. \& Woolridge, W.R. 1927. The effects of chemical and physical changes in environment on resting bacteria. Biochemistry Journal 21: 148-168. https://doi.org/10.1042/bj0210148

Queiroz, O.C.M., Ogunade, I.M., Weinberg, Z. \& Adesogan, A.T. 2018. Silage review: Foodborne pathogens in silage and their mitigation by silage additives. Journal of Dairy Science 101: 4132-4142. https://doi.org/10.3168/jds.2017-13901. https://doi. org/10.3168/jds.2017-13901

Ruijter, J.M., Ramakers, C., Hoogaars, W.M., Karlen, Y., Bakker, O., van den Hoff, M.J. \& Moorman, A.F. 2009. Amplification efficiency: Linking baseline and bias in the analysis of quantitative PCR data. Nucleic Acids Research 37: e45. https://doi.org/10.1093/ nar/gkp045

Schmidt, L., Weissbach, F., Wernecke, K.-D. \& Hein, E. 1971. Erarbeitung von Parametern für die Vorhersage und Steuerung des Gärverlaufes bei der Grünfuttersilierung. (Development of parameters for the prediction and control of the fermentation process in ensiling green forage). Forschungsbericht. Oskar-Kellner-Institut fürTierernährung. Rostock. Deutschland.

Spoelstra, S.F. 1985. Nitrate in silage. Grass and Forage Science 40: 1-11. https://doi.org/10.1111/j.1365-2494.1985.tb01714.x

Weissbach, F. 1968. Beziehungen zwischen Ausgangsmaterial und Gärungsverlauf bei der Grünfuttersilierung [Relations between the herbage and the course of fermentation in ensiling green fodder]. Habilitation: University of Rostock, Germany.

Weissbach, F. 1999. Consequences of grassland de-intensification for ensilability and feeding value of herbage. Landbauforschung Völkenrode (FAL). Contributions of Grassland and Forage research to the Development of Systems of Sustainable Land Use. p. 41-53. 
Weissbach, F., Schmidt, L. \& Hein, E. 1974. Method of anticipation of the run of fermentation in silage making based on the chemical composition of the green fodder. In: Proceedings of the 12th International Grassland Congress. Moscow 1974. Russian Academy of Agricultural Sciences, Lugovaya. https://www.openagrar.de/receive/openagrar_mods_00027701

Woods, L.F.J. \& Wood, J.M. 1982. A note on the effect of nitrite inhibition on the metabolism of Clostridium botulinum. Journal of Applied Bacteriology 52: 109-110. https://doi.org/10.1111/j.1365-2672.1982.tb04380.x

Woods, L.F.J., Wood, J.M. \& Gibbs, P.A. 1981. The involvement of nitric oxide in the inhibition of the phosphoroclastic system of Clostridium sporogenes by sodium nitrite. Journal of General Microbiology 125: 399-406. https://doi.org/10.1099/00221287125-2-399

Xiao, M., Zhu, X., Xu, H., Tang, J., Liu, R., Bi, C., Fan, F. \& Zhang, X. 2017. A novel point mutation in RpoB improves osmotolerance and succinic acid production in Escherichia coli. BMC Biotechnology 17:10. https://doi.org/10.1186/s12896-017-0337-6 